plasma concentrations of the drug was consequent on a reduction in the red cell mass which resulted in increased free concentrations of the drug and the development of nephrotoxicity.

In patients with bone marrow and organ grafts receiving cyclosporin A, as well as those with cirrhosis, there are many other factors that may cause renal impairment, such as organ failure, sepsis, and other nephrotoxic drugs. The present cases emphasise the clinical importance of a sudden reduction in red cell mass and a consequent increase in the quantity of unbound cyclosporin $A$ in the development of nephrotoxicity. Conversely, an increase in red cell mass and binding - for example, as a result of blood transfusion-might lead to a reduction in free cyclosporin $A$ and a decrease in immunosuppressive effect.

The financial support of the Cromwell Hospital and Sandoz Ltd is gratefully acknowledged.

${ }^{1}$ Routhier G, Janossy G, Epstein O, et al. Effect of cyclosporin A on suppressor and inducer $T$ lymphocytes in primary biliary cirrhosis. Lancet 1980 ;ii:1223-6.

2 Keown PA, Ulan RA, Wall WJ, et al. Immunological and pharmacological monitoring in the clinical use of cyclosporin A. Lancet $1981 ; \mathrm{i}: 686-9$.

${ }^{3}$ Al Aghbar M, Alexander G, Neuberger J, et al. Effects of cyclosporin A on suppressor cell function in vivo and in vitro in primary biliary cirrhosis. Gut 1983;24:A970.

4 Kahan BD, Ried M, Newburger J. Pharmacokinetics of cyclosporin in human renal transplantation. Transplant Proc 1983;25:446-53.

5 Lemaire M, Tillement JP. Role of lipoproteins and erythrocytes in the in vitro binding and distribution of cyclosporin $\mathbf{A}$ in the blood. $\mathcal{F}$ Pharm Pharmacol $1982 ; 34: 715-8$.

(Accepted 8 February 1984)

Liver Unit, King's College Hospital, and School of Medicine and Dentistry, London SE5

SIMON ROBSON, MRCP, clinical research fellow

JAMES NEUBERGER, DM, MRCP, senior Wellcome clinical research fellow and honorary senior registrar

GRAEME ALEXANDER, MRCP, honorary senior registrar

ROGER WILLIAMS, MD, FRCP, director of liver unit and consultant physician

Correspondence to: Dr Roger Williams.

\section{Respiratory symptoms related to work in a factory manufacturing cimetidine tablets}

Cimetidine tablets are manufactured by a batch process in which cimetidine base is mixed with excipients that determine the final characteristics of the tablets. The mixture is granulated and ground before being made into tablets. People working near these processes might inhale any of the constituents of the tablets.

\section{Patients, methods, and results}

Four men working in a factory manufacturing cimetidine tablets developed respiratory symptoms related to periods at work. Bronchial provocation tests with cimetidine powder produced an asthmatic reaction in one and nasal reactions in two (table)

We issued a questionnaire and performed skin prick tests and spirometry on three groups of employees defined according to exposure. One group comprised all those daily exposed to dust from cimetidine tabletting; the second comprised virtually all those exposed less than daily but more than once a week; and the third comprised a random sample of those exposed less than once a week. Symptoms of the lower respiratory tract related to work were defined as tightness of the chest, difficulty in breathing, or shortness of breath when hurrying on level ground or walking up a slight hill, with improvement at weekends or during holidays. Nasal symptoms related to work were defined as two or more episodes in the previous 12 months of a blocked, itchy, or runny nose that improved at weekends or during holidays.

Skin prick tests were done with a control solution, with extracts of five common allergens, and with cimetidine solutions at concentrations of 1 and $10 \mathrm{~g} / 1$.

Thirteen $(62 \%)$ of the 21 patients exposed daily, four $(21 \%)$ of the 19 exposed more than once a week, and three $(20 \%)$ of the 15 exposed less than once a week had work related respiratory symptoms. Of eight subjects with symptoms of the lower respiratory tract, seven were in the group
Results of bronchial provocation tests in four men with respiratory symptoms related to exposure to cimetidine dust

\begin{tabular}{|c|c|c|c|c|c|}
\hline \multirow{2}{*}{$\begin{array}{l}\text { Case } \\
\text { No }\end{array}$} & \multirow{2}{*}{$\underset{\text { (years) }}{\text { Age }}$} & \multicolumn{4}{|c|}{ Substances tested } \\
\hline & & Histamine & $\begin{array}{l}\text { Lactose } \\
\text { powder }\end{array}$ & $\begin{array}{c}\text { Tablet } \\
\text { excipients }\end{array}$ & Cimetidine \\
\hline $\begin{array}{l}1 \\
2\end{array}$ & $\begin{array}{l}30 \\
56\end{array}$ & \multirow{2}{*}{$\begin{array}{l}\text { Not tested } \\
14 \% \text { fall in } \\
\text { FEV } 1 \text { at } 4 \mathrm{~g} / \mathrm{l} \\
\text { No reaction } \\
\text { No reaction }\end{array}$} & $\begin{array}{l}\text { No reaction } \\
\text { No reaction }\end{array}$ & $\begin{array}{l}\text { No reaction } \\
\text { No reaction }\end{array}$ & $\begin{array}{l}\text { Late nasal reaction } \\
\text { Late nasal reaction }\end{array}$ \\
\hline $\begin{array}{l}3 \\
4\end{array}$ & $\begin{array}{l}39 \\
27\end{array}$ & & $\begin{array}{l}\text { No reaction } \\
\text { No reaction }\end{array}$ & $\begin{array}{l}\text { No reaction } \\
\text { No reaction }\end{array}$ & $\begin{array}{l}\text { Late bronchial reaction } \\
\text { No reaction }\end{array}$ \\
\hline
\end{tabular}

$\mathrm{FEV}_{1}=$ forced expiratory volume in one second

exposed most often. $\chi^{2}$ testing for linear trend showed a strong relation between the proportion affected in each group and the frequency of exposure to dust $(\mathrm{p}<0.001)$

A positive skin prick test to at least one common allergen was found in $19(34.5 \%)$ of the survey population, but no positive responses to the cimetidine solutions were elicited. No significant relation was found between atopy and work related respiratory symptoms.

Both forced vital capacity and forced expiratory volume in one second were lower in those with work related symptoms of the lower respiratory tract, but the difference was significant only for forced vital capacity $(p<0.05)$ Smoking habit was not related either to disease category or to frequency of exposure, making it unlikely that differences in smoking habit could explain the reduced forced vital capacity in the group with symptoms of the lower respiratory tract.

\section{Comment}

We found that inhalation of cimetidine dust during tablet manufacture may cause asthma or rhinitis, or both, particularly in those most often exposed. Inhalation tests with cimetidine but not with tablet excipients provoked nasal reactions in two cases and a nonimmediate asthmatic reaction in a third. The asthmatic reaction occurred in a patient who did not, before the test, show airway hyperreactivity to inhaled histamine. Thus cimetidine probably does not act as a non-specific irritant in those with hyperreactive airways.

The pathogenesis of the asthma and rhinitis is not certain. There are theoretical grounds for postulating a pharmacological mechanism, 1 but most studies that have examined the effects of cimetidine, when taken in the normal way or when inhaled, on the airways of both normal and asthmatic subjects have shown little if any effect. ${ }^{2}$ Only a proportion of the workforce exposed to cimetidine dust was affected, and their symptoms did not develop immediately after initial exposure. This and the allergic responses that have been reported after both oral ${ }^{3}$ and intravenous ${ }^{4}$ administration of cimetidine suggest that acquired hypersensitivity is a more likely explanation for our findings.

After this study (1979) further measures were taken to control dust. Subsequently only one employee had to be relocated after developing occupational asthma.

1 Lichtenstein LM, Gillespie F. Inhibition of histamine release by histamine controlled by $\mathrm{H} 2$ receptor. Nature $1973 ; 244: 287-8$.

2 Eiser NM. Histamine antagonists and asthma. Pharmacol Ther 1982;17: 239-50.

${ }^{3}$ Delaunois L. Hypersensitivity to cimetidine. $N$ Engl $\mathcal{f}$ Med 1979;300: 1216.

${ }^{4}$ Knapp AB, Grimshaw RS, Goldfarb JP, Farkas PS, Rubin M, Rosenstreich DL. Cimetidine-induced anaphylaxis. Ann Intern Med $1982 ; 97: 374-5$.

(Accepted 2 February 1984)

Brompton Hospital, London SW3 6HP

I I COUTTS, MD, MRCP, clinical lecturer

S LOZEWICZ, MB, MRCP, research fellow

M B DALLY, MB, MRCP, clinical lecturer

A J NEWMAN-TAYLOR, MRCP, MFOM, consultant physician

Solihull Hospital, Solihull, West Midlands

P SHERWOOD BURGE, MRCP, MFOM, consultant physician

Smith Kline and French Laboratories Limited, Welwyn Garden

City AL7 1EY

A C FLIND, BM, BCH, medical director

D J H ROGERS, MB, MRCGP, medical officer

Correspondence to: Dr A J Newman-Taylor. 